\title{
Islam in Australia
}

Prof. Shahram Akbarzadeh

Convenor, Middle East Studies Forum

Alfred Deakin Institute, Deakin University, Australia

Symposium on The State of Muslim Minorities in Contemporary Democracies

Muqtedar Khan (Ed.)

International Institute of Islamic Thought | June 2021

DOI: $\underline{\text { http://doi.org/10.47816/02.001.symposium3.akbarzadeh }}$

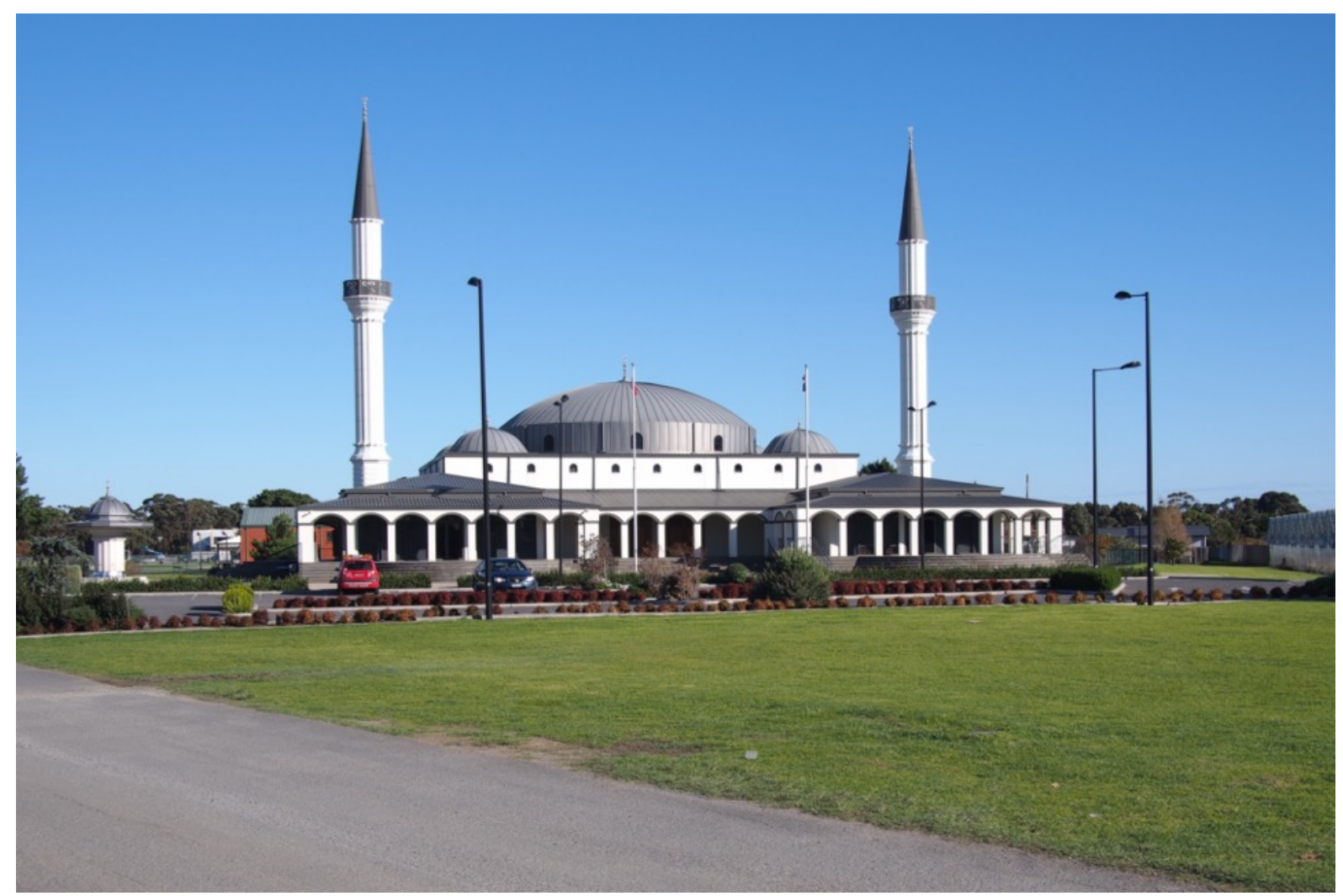

Melbourne Islamic Center

Australia has had a mixed relationship with Islam. While Islam was never accepted as an Australian religion in the $20^{\text {th }}$ century, it was not the target of paranoia. The September 11 attacks in 2001, followed by the Bali bombing (October 2002), significantly changed that. 
Islamic terrorism frontpage news for the following decades. The implied association between Islam and acts of terror grew in the public domain as conservative political leaders sought to leverage public anxiety in the age of "war on terror" for political gains. Right-wing voices on Islam as a religion of hate and terror were uncontested by political leaders, allowing them to gain traction and public currency. This made Australian Muslims feel like outsiders and vulnerable to vilification and physical attack. Guilt by association has hurt Australian Muslims and has been particularly detrimental for Muslim youth. The slur "go back to where you came from" is especially hurtful to Australian Muslim youth; they know no other county than Australia. Two decades after the 2001 attacks, amid rising concerns over right-wing terrorism, political leaders seem to be recognizing the damage of vilifying Muslim communities, but Islamophobia remains.

According to the last Census (2016), the Australian Muslim population is more than 600,000 . This places Australian Muslims at $2.6 \%$ of the total population. Australian Muslims hail from 183 countries. ${ }^{1}$ Islam was first brought to Australia by South Asian camel riders in small numbers, as part of British colonial expansion in the $19^{\text {th }}$ century. However, it was the post-war migration of Muslims from Turkey and Lebanon that established a discernible Muslim presence in Australia. For decades, Turks and Lebanese made up the largest Muslim communities but, in the $21^{\text {st }}$ century, the picture is changing. Migration, refugee settlement, and reunited families from Bangladesh, Iraq, and Pakistan have transformed the make-up of Australian Muslims. The most crucial feature, though, is not the country of origin for Muslim settlers. It is the country of birth for Australian Muslims as a whole. According to the last national Census (2016), more than $36 \%$ of Muslims were born in Australia. This is the largest cohort amongst Muslims. In contrast, Australians born in Muslim-majority countries

\footnotetext{
${ }^{1}$ Rias Hassan, Australian Muslims, a demographic, social and economic profile of Muslims in Australia 2015, International Centre for Muslim and non-Muslim Understanding, University of South Australia, 2015. p. 19
} 
constitute much smaller percentages: Lebanon, 10\%; Turkey, 8\%; Afghanistan, 3.5\%; Pakistan, 3.2\%, and Bangladesh, 2.7\% . As may be expected, migrants gravitate towards their linguistic communities to organize their social, cultural, and religious affairs. This has often meant conducting religious functions in the community's mother tongue. Yet English is the primary language for a growing number of Muslim youth. This is clearly tied to a declining linguistic competency in the mother tongue of their parents - tested by the experience of living in an anglophone environment. This has been an important development in challenging the status of Islam as a foreign religion. ${ }^{2}$

The debate on the place of Islam in Australia has evolved significantly in the $21^{\text {st }}$ century. While the new century has been marked by hyper-sensitivity, mutual mistrust between the government and Muslim communities, as well as Islamophobia, a discernible counter trend is gaining momentum. Efforts to move away from blaming Muslims for acts of terror and associating the whole community with violence has benefitted from two interrelated developments. On the one hand, Australia's political leaders have noted the damage to the social harmony and the fabric of Australia's multicultural society. The subtle and not-so-subtle suspicion of Muslims as potential terrorists allowed the spread of Islamophobia, undermined intercommunity relations, and alienated Australian Muslims. On the other hand, Muslim community organizations have adopted proactive measures to engage with other communities, build interfaith coalitions, and find common ground on countering extremism. This growing trend has gained momentum due to Australia's tradition of multiculturalism and protection of ethnic communities.

\footnotetext{
${ }^{2}$ Mario Peucker, Joshua M Roose and Shahram Akbarzadeh, "Muslim active citizenship in Australia: Socioeconomic challenges and the emergence of a Muslim elite," Australian Journal of Political Science Vol. 49, No. 2, 282-299.
} 


\section{Multiculturalism}

Australia has been generally welcoming to migrants. Muslim migrants from Albania, arriving between the two world wars, have a long history of settlement and were trailblazers for subsequent Muslim migrants in many ways. By building mosques and prayer houses along with organizing halal slaughter to serve the small Muslim community, they prepared the conditions for recognition of Islam in Australia. The 1961 Marriage Act allowed Muslim celebrants to perform marriage in accordance with Islamic traditions and has remained legally binding. Multiculturalism built on these civil rights and formalized group rights for ethnic communities. Australia's policy of multiculturalism was closely tied to the evolution of its immigration policy that took shape in the 1970 s as a result of a double realization: a) that the Australian economy needed to absorb new migrants and not be limited to white European migration, and b) that migrant communities needed to preserve their culture in order to feel at home and commit to Australia. Multiculturalism allowed migrant communities to celebrate their traditions, most visibly in terms of ethnic cuisine and cultural festivals. This policy meant that Muslims from Turkey or Lebanon, for example, could build their mosques, arrange for halal meat, and socialize in their own languages without fear of persecution.

The move to accepting migrants from the Middle East as permanent residents and the subsequent conferring of Australian citizenship upon application, following two years of uninterrupted residency in Australia, were important features of Australian policy. They opened up the political system to formal Muslim participation. While the emergence of a Muslim presence in the political establishment has been very slow, due to language and socio-economic barriers as well as the absence of patronage networks, a handful of Muslims have managed to break through state and federal parliaments. The Australian federal lower house in 2021 includes two known Muslim members: Anne Aly and Ed Husic (both of whom belong to the Labour Party), while the Senate includes one Muslim: Mehreen Faruqi 
(Greens). This minimal presence has given hope to many Muslim organizations regarding their capacity to influence policy debates but, as the discussion on securitization of Muslims and Islamophobia below illustrates, their impact on steering debate has been negligible.

The policy of multiculturalism is centered on ethnic not religious categories and was never intended to recognize collective faith group rights. This has been a contested point in Australia as Muslim community organizations joined hands to speak with a united voice on issues of concern. Australia's anti-vilification laws, such as the 1975 Racial Discrimination Act, have likewise focused on race and ethnicity. The Jewish and Sikh communities managed to gain some recognition as a "people," not simply as a religious community, but for the ethnically diverse Muslims in Australia, this legal framework offered no protection. The adoption of the Racial and Religious Tolerance Act 2001 (Vic), however, was a gamechanger, as it extended protection to all organized religions. This Act provided the legal basis for a significant challenge to the Catch the Fire Ministry (CTM) by the Islamic Council of Victoria (ICV).

In March 2002, the ICV complained that CTM had violated the Act by allowing its pastors to characterize Muslims as liars and demons. The ICV accused CTM of vilifying all Muslims by asserting that the Qur'an promoted violence and looting. In a landmark ruling, the court ruled in favor of the ICV. ${ }^{3}$ Following an appeal, however, the matter was settled out of court. This episode has been celebrated as a win by Muslims and continues to be seen as a vindication of confidence in the Australian legal system.

\section{Securitization}

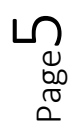

\footnotetext{
${ }^{3}$ https://www.theguardian.com/world/2004/dec/17/australia.religion
} 
While Islamic organizations have been proactive in engaging with other communities and authorities to build bridges, not every Muslim thinks such efforts are warranted. Guilt by association and recurrent insinuation that Muslims are somehow involved in terrorist activity or subscribe to a terrorist ideology have caused distress in the community. Muslims believe they are asked to prove themselves constantly and demonstrate their loyalty to Australia repeatedly. They find this exhausting, humiliating, and ultimately alienating. Muslim youth feel particularly fragile and hurt by the public spotlight, especially because they sense their identity as Australians is being questioned. The sentiment that they are being singled out as a community is a response to the intense scrutiny of Muslims in the age of "war on terror."

Australia's adoption of a myriad of anti-terror legislation is "exceptional" 4 and widely seen as targeting the Muslim community. Prior to 2001, Australia had no national laws that dealt specifically with terrorism. In 2002, the Australian Parliament introduced a range of offences for terrorism and terrorism-related activities. Most of these violations are contained within the Criminal Code Act 1995, which defined a "terrorist act" and provided the means for the classification of a group as a terrorist organization. New anti-terror laws highlighted a significant shift from traditional criminal law in Australia, with the latter focusing on the punishment of individuals after the act and the former concentrating on measures to prevent attacks. In 2014, the Australian Parliament enacted the Counter-Terrorism Legislation Amendment (Foreign Fighters) Act in response to the emergence of the Islamic State of Iraq and Syria (ISIS). ${ }^{5}$ In addition to other measures, it introduced the power to suspend a person's Australian passport for 14 days, made it a crime to enter or remain in a declared area in a foreign country, and created the offence of "advocating terrorism." The Act also

\footnotetext{
${ }^{4}$ McGarity, Nicola and Williams, George (2014) "From covert to coercive: A new model of surveillance by intelligence agencies," in Davis, Fergal, Nicola McGarrity, and George Williams (eds.) Surveillance, counterterrorism and comparative constitutionalism (London: Routledge), p. 244.

${ }^{5}$ Parliament of Australia (2014) "Counter-terrorism legislation amendment (foreign fighters) bill 2014," available at https://www.aph.gov.au/Parliamentary_Business/Bills_LEGislation/Bills_Search_Results/Result?bId=s976
} 
introduced the power to cancel welfare payments to persons involved in terrorism and lowered the legal threshold to allow the arrest of an individual for terrorism misdemeanors without a warrant. ${ }^{6}$ This was justified in terms of the need to address the domestic threat posed by Australians engaging in and returning from overseas conflicts, such as in Iraq and Syria. $^{7}$

A coalition of civil libertarians, as well as church organizations, have voiced concerns about the ramifications of the anti-terror laws. In 2015, the Australian Law Reform Commission reported that many anti-terror laws restrict freedoms of religion, speech, movement, and association. ${ }^{8}$ It is widely believed that the application of anti-terror laws target Muslims. Despite claims of neutrality, Australia's anti-terror laws are seen as contributing to the disproportionate representation of Muslims in prisons and the tarnishing of the whole community. In 2017, the United Nations Committee on the Elimination of Racial Profiling raised concerns for the Arab and Muslim population in Australia, noting that "public anxiety about terrorism has heightened prejudice towards and discrimination against them."9 The committee also highlighted Australia's discriminatory counter-terrorism measures and police practices, while warning the Australian government about the risks associated with racial profiling.

Depicting Muslims as potential terrorists has led to the securitization of the whole community. This has stoked the fire of Islamophobia in the public domain and resulted in the

\footnotetext{
${ }^{6}$ Australian Government (2014) "Counter-terrorism legislation amendment (foreign fighters) act 2014," Federal Register of Legislation, available at https://www.legislation.gov.au/Details/C2014A00116

${ }^{7}$ Attorney General (2014) "Explanatory memorandum: Counter-terrorism legislation amendment (foreign fighters) act 2014," available at https://www.legislation.gov.au/Details/C2014B00195/Explanatory\%20Memorandum/Text

${ }^{8}$ Australian Law Reform Commission (2015) "Traditional rights and freedoms - encroachment by Commonwealth laws," July 17, available at https://www.alrc.gov.au/wp-content/uploads/2019/08/alrc 127 interim report.pdf

${ }^{9}$ Soutphommasane, Tim (2017) "Statement to UN committee on the elimination of racial discrimination Geneva, Switzerland," Australian Human Rights Commission, November 27, available at https://www.humanrights.gov.au/news/speeches/statement-un-committee-elimination-racial-discriminationgeneva-switzerland
} 
marginalization of Muslims. The feeling among many Muslims that they are fighting a losing battle has only begun to subside as Islamophobia morphed into white-supremacy terrorism, and Muslims have become victims of violence. The killing rampage by an Australian national in Christchurch (New Zealand) in March 2019, that left 51 Muslims dead and 40 injured, was a turning point.

In 2020, the Australian Security Intelligence Organisation (ASIO) revealed that its workload on monitoring and following up on threats from far-right extremists took up to $40 \%$ of its resources. ${ }^{10}$ This revelation has significantly changed the public discourse and made political leaders more aware of the risks involved in implying Muslim community complicity in acts of terror that has fueled the flames of Islamophobia. In March 2020, Australia added a far-right extremist group (Sonnenkrieg Division) to the list of designated terrorist organizations for the first time - a milestone moment.

\section{Islamophobia}

Anti-Islam expressions have been a serious issue in Australia in the $21^{\text {st }}$ century. Islamophobia has centered around key themes of Muslims as a security threat and a danger to the Australian way of life. Halal food, hijab, and mosques, as the most visible public manifestations of Islam, have been the target of Islamophobic attacks. In 2017, the right-wing Q Society's Kirralie Smith launched a campaign against halal food, alleging the halal industry funded terrorism and imposed a hidden tax on Australian consumers. This accusation had the support of a number of right-wing members of the parliament, who were incidentally backing the right-of-center coalition government of Prime Minister Turnbull. This put the P.M. in an awkward situation as he was trying to reduce tensions and push

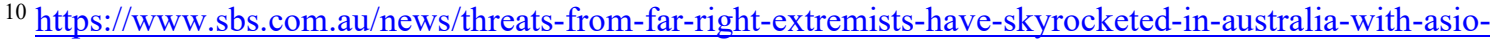
comparing-tactics-to-is
} 
against Islamophobia (noted below). Smith's allegations were met by a defamation court case, brought on by the Halal Certification Authority. The matter was resolved out of court. Following a long meeting between the two parties, Smith issued a public apology, and the case was withdrawn. ${ }^{11}$ This was a legal victory, but the social impact of the case continues to reverberate.

Among the ugliest form of Islamophobia are attacks on Muslim women wearing the hijab. Cases of public assault on unsuspecting Muslim women in public tend to escalate following terror attacks by jihadists. The rise of ISIS and reports of some Australian Muslims trying to join ISIS stirred trouble. Instances of verbal and physical attacks on hijabi women rose significantly, but often went unreported or were deemed too trivial for police follow-up. This led to the formation of the Islamophobia Register to document cases of Islamophobic attacks. ${ }^{12}$ The 2017 report on Islamophobia in Australia and the subsequent Islamophobia in Australia II (2017-2019) captured the persistence of the problem. ${ }^{13}$ Among the challenging issues identified in the reports was the role of bystanders. In more than half of such cases of religiously motivated assault in public, bystanders did not intervene.

The scale of the problem has not gone unnoticed by many political leaders. Measures to address the targeting of Islam and Australian Muslims include a range of training programs for law enforcement agencies to improve cultural and religious sensitivity. Other steps include the hosting of iftar dinners to celebrate and acknowledge the holy month of Ramadan, allowing Muslim leaders to dine with government officials, although this tends to

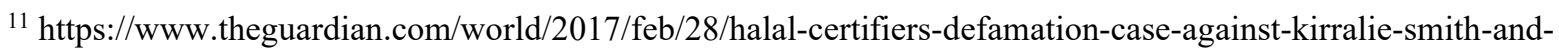
q-society-settled-out-of-court

12 See https://www.islamophobia.com.au/

${ }^{13}$ Iner, Derya, ed. Islamophobia in Australia report II (2017-2018). Sydney: Charles Sturt University and ISRA, 2019.
} 
be done at the state, not federal, level. The only exception was the first and last iftar dinner to be hosted by a prime minister (Malcolm Turnbull) in 2016. ${ }^{14}$

Fethi Mansouri, UNESCO Chair in Cultural Diversity and Social Justice, has argued that the process of Islamophobia has meant the denial of "individual agency" and "diverse cultural and religious identities" of Australian Muslims. ${ }^{15}$ The lumping of all Muslims into a homogeneous whole and labelling them as dangerous is problematic on so many levels. Many Muslim community organizations have sought to contest this trend and offer their own narrative on what it means to be Muslim in Australia. They have appealed to Australia's legal system to redress incidents of hate and vilification and to build channels of communication with government agencies to prevent threats emerging from the Muslim community or to the Muslim community.

\section{Conclusion}

Successive surveys of Muslims in Australia have documented that they do not see a contradiction between being loyal to Australia and performing their religious duties. Australia is cherished by its Muslims population for the freedom it offers and the protection of their beliefs, often absent in many Muslim countries. This message is repeated by many imams who praise Australia's legal framework for providing protection to Muslims against hate, vilification, and discrimination. In the words of one imam, this is the closest one might get to the idealized Islamic model of just rule. ${ }^{16}$ This is high praise, but not every Muslim feels this

\footnotetext{
${ }^{14}$ https://www.sbs.com.au/news/turnbull-first-pm-to-host-iftar-for-ramadan

${ }^{15}$ Fethi Mansouri, "Islam and Muslims in Australia: The social experiences of early settlement and the politics of contemporary race relations," Politics and Religion, Vol. XIV, No.1 (2020), p.141.

${ }^{16}$ Shahram Akbarzadeh, "The Muslim question in Australia: Islamophobia and Muslim alienation," Journal of Muslim Minority Affairs, 2016, Volume 36, Issue 3, pp. 323-333.
} 
way. The phenomenon of Islamophobia and the heavy-handed securitization of Islam and Muslims in the $21^{\text {st }}$ century in Australia has hit Muslim youth hard.

Muslim youth often have no first-hand experience of life in the country of origin of their parents and no such point of reference. Their lives in Australia have been overshadowed by constant explicit and implicit assertions that they represent something alien to Australia; that they do not fit and, ultimately, that they are not welcome here. It is not surprising that some Muslim youth internalize this message and question their future in Australia. This is an urgent challenge, acknowledged by community leaders and government agencies. However, reaching disillusioned youth is hampered by a sense of distrust that government agencies hold against traditional Islamic leaders.

The problem of Islamophobia and Muslim alienation are ultimately political issues and very much within the domain of political leaders to address. The silence of political leaders, and at times explicit anti-Islam claims, has allowed Islamophobic ideas to lose their "taboo" status and gain currency. Nevertheless, the rise of far-right extremism in recent years has been a wakeup call for the political class. The Christchurch attacks by an Australian was a jolt to the public and to political leaders. Media commentators labelled the attacks as terrorism and the gunman received the first terrorist conviction in New Zealand.

Changing the dominant discourse that posits Islam as a challenge to Australian values and Muslims as not integrating in Australia is a gradual process. Yet the shift is discernible. Political leadership appears mindful of the damage Islamophobic gestures have made to community relations, opening the field to far-right extremism. This may be vindicating the trust that Muslim community organizations have placed in the intrinsic principles of justice and fairness in Australia. 
Author Bio

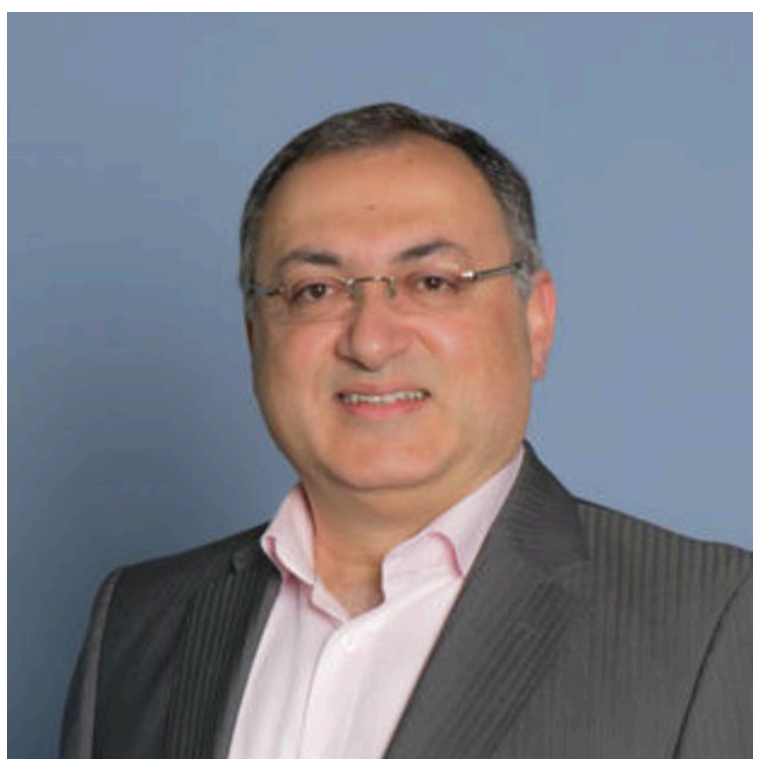

Professor Shahram Akbarzadeh is Research Professor in Middle East and Central Asian Politics at Deakin University and the Deputy Director (International) of the Alfred Deakin Institute for Citizenship and Globalisation, Deakin University (Australia). He held a prestigious ARC Future Fellowship (2013-2016) on the Role of Islam in Iran's Foreign Policy-making and recently completed a Qatar Foundation grant on Sectarianism in the Middle East. Prof Akbarzadeh has an extensive publication record and has contributed to public debate on topics such as democracy and political processes in the Middle East, regional rivalry and Islamic militancy. He has also researched and published on Muslim integration in Australia and citizenship debates. Prof Akbarzadeh was the founding President of the Australian Association of Islamic and Muslim Studies (AAIMS) Inc. (2016-2019) He is the convenor of the Middle East Studies Forum. 